\title{
METHODOLOGY OF TEACHING A FOREIGN LANGUAGE USING THE CONCEPT OF HUMANE PEDAGOGY
}

\author{
Oksana Akifyeva ${ }^{1}$, Elmira Uteubayeva ${ }^{2}$ \\ ${ }^{1}$ E.A. Buketov Karaganda University, Karaganda, Kazakhstan \\ ${ }^{2}$ E.A. Buketov Karaganda University, Karaganda, Kazakhstan \\ ORCID iD: 0000-0002-1648-114X
}

\begin{abstract}
This article describes the methods of teaching a foreign language at school using the concept of humane pedagogy. The authors analyze the current situation in a modern school, and also propose specific methods of working with educational material in English lessons, which help an English teacher to form humane personality traits in students. The article also draws special attention to the potential of literary texts, proverbs, sayings and features of English speech etiquette for educating students from the position of a humane approach to teaching.
\end{abstract}

\section{INTRODUCTION}

The entire history of mankind is saturated with the ideas of humanism. This led to the gradual emergence of a humanistic worldview. Ideas about people's voluntary renunciation of social inequality, renunciation of oppression of the weak and a call for mutual support can be clearly traced in Christ's Sermon on the Mount. But long before the advent of Christianity, the wisest representatives of humanity, such as Plato, Gandhi, Confucius, promoted the ideas of humanism. The principles of humanism today contain almost all world religions: Buddhism, Islam, Christianity, etc.

Currently, it is necessary to build a system of training and education based on a humane and personal approach. It is today that we begin to grow a society driven by intrinsic motivation [Instructional and methodological letter "On the features of the educational process in secondary education organizations of the Republic of Kazakhstan in the 2021-2022 academic year", 2021].

It is necessary to organize the educational and educational processes at school in such a way that the children are loaded with interest.

We believe that if every teacher, not only in our country, but all over the world, took these words as the basis of all his work, then humane pedagogy would become not a science, but the way of thinking of the entire teaching community.

\section{MAIN PART}

Today we must think about whether the person of the 21 st century has become more humane? It is rather difficult to answer this question in the affirmative, since the facts suggest otherwise. If we consider the last century, then humanity has survived not only two world wars, but also a large number of small local wars that claimed millions of human lives. To this list should be added the victims of political repression and victims of many terrorist attacks.

Working on the experimental site of the Secondary School №23 in Karaganda, we studied the data presented by psychologists on the analysis of the level of anxiety among students. And if the level of anxiety among primary school students is at a fairly low level ( $8 \%$ of respondents), then by the 7 th- 8 th grade the level of anxiety rises by almost $13 \%$ and remains up to grade 10 . In the 11 th grade, this level rises again by $3 \%$. This statistic suggests that special attention to the education of humane personal qualities should be paid to students in grades 5-6, who have a sharp jump in the level of anxiety in two years. Psychologists associate this with the age-related psycho-physiological 
characteristics of students. At this age, there is a pearl of character and a revision of values. Most of the problems for the teachers of this school are associated with students in grades 6-7. It should be noted that the analysis of the situation in school \# 23 showed that in 2018 it was a 7 th grade student who committed a complete suicide.

Observing the teachers of the English language at school №23, we found that $15 \%$ of teachers still use imperative appeals to students in their speech. As an example, we can offer several phrases of English teachers that we noticed in the lessons. They are shown in Table 1.

Table 1. Imperative phrases of English language teachers of the school №23, used during lessons

\begin{tabular}{|l|}
\hline Phrase in English \\
\hline Read and translate the text! \\
\hline Explain the meaning of this word! \\
\hline Give the example! \\
\hline Answer the question! \\
\hline Make up a story about...! \\
\hline Go to the blackboard! \\
\hline Listen to the song! \\
\hline Complete the sentence! \\
\hline
\end{tabular}

Having looked carefully at the phrases in Table 1, one can come to the conclusion that these teachers do not offer students to complete a certain task, but order them without leaving the right to choose.

We believe that more polite phrases and expressions should be used when communicating with students. Observing the remaining $85 \%$ of English teachers at school №23, we came to the conclusion that it is very easy to achieve this by using modal verbs in speech as often as possible. In this case, the teacher's phrases sound more polite and softer: "Could you read this text, please?", "Will you go to the blackboard, please?" etc. Any phrase of the teacher can be softened with phrases and words such as "please", "will you?", "Would you", etc.

We also believe that it is not only the teacher's speech that has an educational impact on students. Sometimes gestures, facial expressions, gaze or posture are more expressive. An English teacher (and not only) should give up not only inhuman phrases, but also inhuman gestures such as a stern facial expression, manifested by a frowning forehead or pursed lips, or a threat with an index finger, which the teacher waves in the air as if threatening retribution for a misdemeanor or warning of impending punishment.

Estonian scholars show that even the location of the teacher in the classroom (classroom) can affect the psychological climate during the lesson. The teacher's face-to-face position across the table can heighten tension with students, and conversely, placing the teacher next to the student encourages teamwork and collaboration.

That is why we believe that even the arrangement of tables in the classroom in English lessons is of great importance. The most appropriate, in our opinion, is the arrangement of tables with the letter "P" instead of placing desks in rows. This arrangement of furniture allows the teacher to move closer and further away from the students, as well as freely move around the classroom. This will also facilitate live communication not only between students and the teacher, but also with their classmates, whom they will see in the face, and not their backs of the head.

We also analyzed the textbooks used by teachers of the KSU "OSH №23" in Karaganda in foreign language lessons. The analysis showed that, on average, only $10 \%$ of the textbook's material and exercises are aimed at fostering humane personality traits such as kindness, mercy, politeness, tact, etc.

The analysis showed that textbooks for grades 6-7 contain the smallest content of humane material, although at this stage of development children are the most vulnerable in emotional and 
psychological terms. For example, as noted above, a large number of completed suicides and attempts to commit suicides happen precisely with children of this age.

If we consider specifically the texts, then of all the texts, only $2 \%$ are problematic, which make students think. All the rest of the texts are purely informative and are the usual statement of already known facts. Some of the texts are simply descriptions of any sights or famous people, without emotional or spiritual connotations. And if you look at the training exercises, $70 \%$ of them begin with the phrases "read" and "complete". Another $28 \%$ of the exercises begin with the word "answer", and involve only answers to questions. The analyzed textbooks also contained "true / false" exercises, which accounted for less than $1 \%$ of the total number of exercises.

Thus, it should be noted that the material of textbooks on the English language practically does not contain an educational or spiritual and moral component. Teaching English according to these textbooks is extremely informative, aimed at learning vocabulary and grammar.

The aspects discussed above, related to the organization of both verbal and non-verbal communication with students, will definitely contribute to the humanization of the educational process in English lessons.

Applying a humane approach to teaching can also help an English teacher cope with another problem that we often encounter in class - the fear of making a mistake or saying it wrong.

Frequent correction of mistakes by the teacher, accompanied by an interruption in the student's speech or fixation of mistakes in writing during the answer, negatively affects the motivation of students to learn, since it violates the psychologically comfortable environment in the classroom, although it is done by the teacher with the best intentions. Instead of pondering the answer, the student begins to feel fear, is distracted by observing the teacher's behavior, which over time becomes an insurmountable barrier in communicating in a foreign language. This fear can ultimately lead to a negative attitude towards English as a whole as a subject.

In this case, all statements of students in English can be roughly divided into three types:

1. not distorted phono-grammatically and understandable

2. distorted phono-grammatically, but quite understandable

3. distorted phono-grammatically and absolutely incomprehensible.

We do not urge the teacher to abandon the control and correction of students' foreign language speech, but it is obvious that statements of the third type are subject to mandatory correction at school. And even the correction of errors of this type from the point of view of a humane approach can be carried out not as a correction and an indication of an error, but as a clarification and an attempt to understand what the given student wanted to say. [Vaysburd, Kuzmina, 1999]

Also, in our opinion, a humane attitude towards students during test, summative and test work will significantly reduce the level of anxiety among students. In no case should these types of tests be punished for all the misdeeds committed during the study of the topic, on the contrary, they should be in the nature of confirmation of the success that the student was able to achieve by studying a topic that is rather difficult or not entirely clear to him. Another important point from the point of view of education of humanity, in our opinion, is the differentiation of this kind of work. In our opinion, it is inhumane to offer tasks of the same difficulty to students with high and low motivation to learn. In relation to some, this creates a situation of constant easy success, and in relation to others, a situation of deliberate failure, which can lead to an underestimation of the student's self-esteem.

We believe that the teacher's behavior during such tests is also very important. The teacher needs to create the most comfortable conditions in an environment that is already alarming for students. Calm behavior and minimal movement around the classroom will help to show respect for the independent mental activity of students. The teacher should not unnecessarily walk through the rows, observing the students, causing them to irritate. It is clear that many teachers in this way want to avoid the use of cheat sheets by certain students, but by doing so they show their distrust of the rest of the students. We consider it completely normal for a student to use a textbook in order to remember a word or rule. This in no way detracts from his mental abilities, but gives him confidence and obviously creates a situation of success. Also, if during independent work a student raises his hand 
and turns to the teacher for help, then the teacher should come up and answer the question in a whisper, without distracting the others [Grigorieva, 2000]

The same humane approach is required for the next stage of the verification work - the announcement of the results. In our opinion, first of all, the teacher should note the success of the entire class as a whole and, possibly, each student individually. After that, you can proceed to correcting errors without naming their authors. It will be humane to select the most common mistakes in the students' work, and to correct mistakes in the form of repetition of those that caused particular difficulty for students during the test.

The teacher can also show humanity during the announcement of the homework. We suggest giving students a choice through compulsory and optional assignments. It is assumed that one or two required tasks will be completed by all students, and optional tasks will be completed only by those who wish.

The practice of work at school and at the university shows that it is advisable to alternate traditional and innovative teaching technologies.

Let us turn to the educational possibilities of the educational text in English lessons. It should be noted that the potential of texts is being studied not only by linguists, but also by psychologists, sociologists, and philosophers. We believe that when teaching a foreign language, a teacher should first of all take into account the educational capabilities and values of the educational text. The educational text should carry significance from the point of view of the formation of the student's personality, endowed with such humane qualities as kindness, responsiveness, tolerance, mercy, sympathy, etc. Considering this fact, in our opinion, the educational text should contain a moral problem that will pose a student facing a moral choice. As noted above, textbooks that are used in Kazakhstani schools contain mostly informative texts that do not carry any morality. Below, using specific examples, we will attempt to show the educational potential of the educational text from the point of view of educating humanity in English lessons.

We believe that the literary texts of such outstanding authors as O. Henry, O. Wilde, M. Twain, J. London, Aesop and other authors can in practice help an English teacher in such a difficult matter at the present time as the formation of humane personality traits, as well as a humane worldview in students. Even V.A. Sukhomlinsky pointed out that "for the education of noble feelings, works of art are needed that would awaken in children the idea of the highest value of the world man"

Regional and local history texts have invaluable educational potential, along with artistic ones. Using such texts in his lessons, the teacher instills in his students such important humane qualities as patriotism, loyalty, devotion, pride and love for their homeland. Living on the territory of the Republic of Kazakhstan, we try, within the framework of integration, to more often refer to texts from the field of geography of Kazakhstan, Kazakh literature and the history of Kazakhstan. Working on such texts, students not only learn more about the culture, traditions and characteristics of their people, but also analyze the achievements of their country in various spheres of politics and economics. As a work on such texts, we invite students to write their opinion on this or that aspect, as well as analyze individual actions of outstanding representatives of the Kazakh people, putting themselves in their place.

The proverbs and sayings, their educational value, their wisdom does not need proof, since they contain the wisdom of many generations, can be of great help to the teacher of the English language in the formation of the humane qualities of the individual. These short but capacious sayings were created by the people themselves, and their wisdom is addressed to all of humanity in general and to each person in particular. Proverbs and sayings contain advice, instructions, requirements, wishes that are designed to help a person facing a difficult moral choice. These short aphorisms help a person make decisions in difficult situations and sound like a ready-made practical guide to action. "Live and learn", "Handsome is as handsome does", "Good can never grow out of evil", "Early to bed and early to rise makes a man healthy, wealthy and wise", "A man is known by the company he keeps ", “" East or West, home is best "- these and many other proverbs and sayings are designed to educate the young generation to be kind, educated, responsible, decisive, prudent, respect elders, love their homeland, etc. 
A huge number of English proverbs and sayings are an important tool for educating students for humanity. Ivanov VA, with whom we completely agree, believes that "the deeper one understands their meaning, the faster this knowledge will take the form of personal views and act as motives, actions and attitudes of behavior" [Ivanov, 1998]

In our teaching practice, we try to use English proverbs and sayings in lessons as often as possible. We invite colleagues to use them as an epigraph for each lesson. In the English language, there are proverbs and sayings related to any topic prescribed in a foreign language teaching program. Starting each lesson with a specific proverb or saying and spending 3-4 minutes discussing it with students will make a significant contribution to the formation of the humane qualities of the student's personality.

In the course of working on English proverbs and sayings, our students learned to look seriously at many things from the standpoint of goodness and justice.

With regard to modern English etiquette, we believe that learning it can also help an English teacher develop humane personality traits in students. The very concept of etiquette appears to us primarily as a means of communication, regulation of relations between people who enter into this communication. As Academician D.S. Likhachev "at the heart of all good manners is one concern the care that a person does not interfere with a person, so that everyone would feel good together" [Likhacheva, 1995] The principles of humanism today are the fundamental principles of speech etiquette. These principles include courtesy, delicacy, humility, courtesy, and accuracy.

Expression of gratitude occupies an important place in the specifics of English speech etiquette. In the modern understanding of students, the expression of gratitude in English is the phrase "Thank you". Thus, the task of the English teacher is to help his students learn and practice the many expressions of gratitude in English. The usual phrase "Thank you!" can be replaced with such wonderful beautiful expressions of gratitude as "Thank you with all my heart!", "A thousand thanks!", "Thank you ever so much!”, "Much obliged to you!", "I am deeply indebted to you! " and etc.

Referring to the research of M. Aisenstein and J. Bodman, it should be noted that native speakers, when expressing gratitude, are always guided by a certain system of rules that allows them to choose the appropriate gratitude phrases in each specific situation. [Ariyan M.A., 1991] So, for example, when receiving a gift, the phrase "Oh, how beautiful! How did you know? It's just what I wanted!", And when leaving the dinner party, the guest should say "Thank you for inviting me. I had a good time". The teacher should explain these and other features of English speech ethics to his students with specific examples.

Also, an English teacher should show in practice how all of the above techniques, in our opinion, will contribute to the humanization of the educational process in English lessons, and will also help to increase the motivation of students to learn and, as a result, the quality of knowledge in the subject.

\section{CONCLUSIONS}

All teachers who plan to apply a humane approach in education should remember that for this it is necessary to combine all the components of a given personal quality and present them as one stable character trait. And, for this, it is necessary, first of all, to take into account the interests of children.

In conclusion, we want to note that the most important components for the development of functional literacy of students are already available from the beginning in every child. You just need to motivate the child so that he, on his own, consciously involves himself in the learning process. 


\section{REFERENCES:}

Ariyan M.A. (1991) Using the educational potential of speech etiquette in a foreign language // Foreign language at school. No. 2, 9-12.

Grigorieva E.G. (2000) Education of humanity among students in the process of teaching a foreign language // Chuvash State University. I.N. Ulyanov, 218.

Instructional and methodological letter "On the features of the educational process in secondary education organizations of the Republic of Kazakhstan in the 2021-2022 academic year." (2021) // Nur-Sultan: NAO named after Y. Altynsarin, 338.

Ivanov V.A. (1998) German-Chuvash ethnic pedagogy. - Cheboksary Chuvash state Institute of Humanities. Sciences, 240.

Likhacheva L.S. (1995) School of etiquette: teachings just in case // Yekaterinburg: Middle-Ural. book publishing house, 448.

Vaysburd M.L. Kuzmina E.V. (1999) The role of individual characteristics of students in teaching foreign language oral communication // Foreign languages at school. No. 1, 5-10 